\title{
The Moderating Effect of Non-audit Services Fee on Aggressive Tax Planning: Empirical Evidence From Malaysian Listed Companies
}

\author{
Rosmaria Jaffar ${ }^{1,2}$, Chek Derashid ${ }^{2} \&$ Roshaiza Taha $^{3}$ \\ ${ }^{1}$ Faculty of Business and Management, Universiti Sultan Zainal Abidin, Kuala Nerus, Terengganu, Malaysia \\ ${ }^{2}$ School of Accounting, Universiti Utara Malaysia, Sintok, Kedah, Malaysia \\ ${ }^{3}$ Faculty of Business, Economics and Social Development, Universiti Malaysia Terengganu, Kuala Nerus, \\ Terengganu, Malaysia \\ Correspondence: Chek Derashid, School of Accounting, Universiti Utara Malaysia, 60100, Sintok, Kedah, Malaysia.
}

Received: October 1, 2020

Accepted: December 19, 2020

Online Published: January 24, 2021

doi:10.5430/ijfr.v12n3p240

URL: https://doi.org/10.5430/ijfr.v12n3p240

\begin{abstract}
The purpose of this study is to examine the moderating effect of non-audit services fees on the relationship between size, profitability, leverage, capital intensity, inventory intensity, financial distress and ethnicity with aggressive tax planning. This study uses a sample from companies listed on the Malaysian (Access, Certainty, Efficiency (ACE) Market from 2014 to 2018, comprising of 105 firm year-observations. The finding shows that the non-audit services fee moderate the relationship between size, profitability, leverage, inventory intensity, financial distress and ethnicity with aggressive tax planning except for capital intensity. It is hoped that the finding can assist readers in understanding the nature of companies listed on the ACE Market, particularly their behaviour towards tax planning. This study contributes to knowledge in the areas of financial accounting and taxation specifically on aggressive tax planning, by introducing the moderating variable of non-audit services fee. The uniqueness of the use of companies listed on the Malaysian ACE market will provide new avenue on the discussion on an aggressive tax planning issue, which usually more focus on big firms. The framework used in the present study could serve as a basis for research in other developing countries or regions.
\end{abstract}

Keywords: aggressive tax planning, Malaysia, ACE market, size, ethnicity, financial distress, non-audit services fee

\section{Introduction}

A growing body of academic research on aggressive tax planning has come to the fore in recent years and has been very important for industry players and academicians (Martinez, 2017). Aggressive tax planning is known to be one of the ways that can be employed to minimize the tax burden, especially by corporate taxpayers (Wahab, Ariff, Marzuki, \& Sanusi, 2017). This activity can be undertaken by companies that exploit any loophole in the tax law to gain tax advantage from the mismatch between the country's tax rules, which could then lead to minimizing the tax burden, and subsequently, avoiding the payment of their fair share of taxes. Companies that are deemed to be socially responsible are expected to comply with the tax law and pay the fair amount of tax (Salihu, Annuar, Normala, \& Obid, 2015). However, as tax has always been seen as a burden, companies tend to utilize any opportunity to reduce the tax, for example by employing various tax planning strategies (Dhamara \& Violita, 2018; Eskandar \& Ebrahimi, 2020; Mgammal, 2015; Oktaviyani \& Munandar, 2017; Sadjiarto, Hartanto, Natalia, \& Octaviana, 2020).

Aggressive tax planning activities conducted by companies will result in the lowering of the companies' effective tax rate (ETR) as compared to the statutory tax rate (STR) (Kasim \& Saad, 2019). Previous studies have investigated the determinants or factors that influence companies to pay a lower ETR than STR. Lower ETR shows that companies involve in high aggressive tax planning activities (Higgins, Omer, \& Phillips, 2015; Klassen, Lisowsky, \& Mescall, 2016). Despite the long list of studies on aggressive tax planning activities undertaken by companies, the discussion shall continue as there are a lot of changes in the industries that worth to be researched for. Besides, it is worth to also include the moderating variable rather than a direct relationship, to promote new evidence on the determinants of aggressive tax planning. A moderating variable is introduced when they are an inconsistent or unpredictably weak relationship between the independent variable and the dependent variable (Baron \& Kenny,1986). Binding from 
these arguments, we considered introducing the non-audit services fee as a moderating variable to provide new avenue in the discussion of aggressive tax planning determinants.

The remainder of this paper is divided into five sections. Section 2 discusses the literature review and the development of research hypotheses. Sample selection, variable measurement and the model are presented in section 3. Section 4 discusses the empirical results, and finally, Section 5 concludes the study and presents suggestions for future research.

\section{Literature Review and Hypothesis Development}

\subsection{Non-audit Services Fee as Moderator}

Recently, it is common for auditing firms to offer non-audit services (NAS) in addition to audit services to enhance the quality of reports produced. Companies that incur NAS must disclose the fee in their company's annual report. The Sarbanes-Oxley (SOX) Act has strict limitations on the types of NAS and companies are required to disclose it separately, based on its type, especially for tax services (Hogan \& Noga, 2015). Previous researchers have given several definitions of NAS fee. For example, Firth (1997) defined NAS as services provided by the auditor, which include tax consultancy, systems consultancy, management advice, international business advice, human resource management advice, and financial and investment consultancy. Santos, Cerqueira, and Brandao (2015) and Haron, Ismail, Ganesan, and Hamzah (2016) agree that NAS fee as the fee paid by the companies to the auditor who provided services other than audit services which also includes management advisory services or consulting, tax services and accounting advice. The definition of NAS fee in Choudhary and Koester (2017) study are more focus to any fee paid to audit firms only for tax services.

It is believed that the NAS sought after by most of the small and medium businesses is taxation services ( Ganesan, Haron, Ismail, \& Pitchay, 2017). This is due to the limited knowledge in tax system hindering them from having a company's strategic planning for their tax-related aspects. This is often the major drawback for them due to the minimum benefits they can obtain from their own strategies compared when seeking professional advice. Besides, the complexity of the tax system, which usually opposed the accounting treatment, adds to the difficulties in tax planning which may result in evasion activities. This argument is confirmed by Tee, Boadi, and Opoku (2016) that small and medium businesses have limited knowledge about tax matters. Therefore, tax services, which include income tax compliance and tax planning provided by external auditors, play an important role in the services provided to small and medium businesses (Choudhary and Koester, 2017). Recruiting qualified personnel and hiring professionals is seen as a good strategy in helping a company to solve the problem in tax matter (Laguir, Elbaz, \& Laguir, 2015; Mgammal, 2015; The Star, 2017).

Public accounting firms which provided both audit services and tax services tend to encourage companies' aggressive tax planning behaviour (Klassen et al., 2016; McGuire, Omer, \& Wang, 2012). Due to this, companies which have hired an auditor for tax services to plan for their tax, have been found to pay higher fees for external audit services. This further resulted in a significant reduction in ETR and enabled the company to enjoyed higher cash tax savings and lower risk. The result is contradicted for companies which do not engaging auditor in the tax planning strategies (Chyz, Naiker, Gal-Or, \& Sharma, 2017; Donohoe \& Knechel, 2014). The result is consistent with studies done in German, Tehran and Malaysia where they found a negative relationship which indicated that the higher the NAS fee the lower the companies' ETR (Burggrael, Wtrin, \& Wei, 2017; Hussin \& Noor, 2012; Saremi, Mohammadi, \& Nezhad, 2016) showing aggressive tax planning strategies has been implemented. Previous studies reveal that auditors who provide NAS i.e. tax services are providers who can develop more effective tax strategies because of the knowledge spill-over to their client's business, internal processes, systems, and industry, as they have access to extensive internal financial information (Chyz et al., 2017). The following discussion has been narrowed to the role of NAS in the relationship between ETR and the determinants.

\subsection{The Influence of NAS Fee on the Relationship Between Company Size and Aggressive Tax Planning}

Size is an important factor that has been used to determine audit fees and ETR. Aggressive tax planning usually relevant for big size of companies as they have bare higher tax burden due to their large scale of operation. Pham, Duong, Pham, and Ho (2015) found that there is a positive relationship between size and audit fees, where the larger the company, the higher the fees for audit services, due to the number of works required. This result is consistent when focusing on NAS, where larger companies are likely to incur a higher amount of NAS due to the complexity of the operations (Bottaro, Castro, \& Peleias, 2015; Hassan \& Naser, 2013; Musah, 2017). Diverting the discussion to the role of ETR and companies size, the direction of the relationship is the inverse direction, where the bigger size of the firm, the lower their ETR (Adhikari, Derashid, \& Zhang, 2006; Hadjidema, Stamatopoulos, \& Eleftheriou, 2016; 
Nomura, 2017; Noor, Mastuki, \& Bardai, 2008). Thus it is quite interesting to see the result of the analysis when including NAS as the moderating to see how it will influence the relationship between size and aggressive tax planning undertaken by companies. It is believed that NAS may influence the relationship between size and aggressive tax planning. Therefore, this study hypothesizes that:

H1: The relationship between company size and aggressive tax planning is moderated by NAS fee.

\subsection{The Influence of NAS Fee on the Relationship Between Profitability and Aggressive Tax Planning}

In terms of profitability, higher profits will lead to higher audit fees as companies are seen having higher business activities or transaction that require a thorough review of companies records (Januarti \& Diponegoro, 2018; Rusmanto \& Waworuntu, 2015). Due to that, the available information on company revenue and expenses will be thoroughly audited by the auditor (Joshi and Al-bastaki, 2000). This is consistent with the study by Musah (2017) in Ghana, where the researcher found a positive relationship between the profit of the company and audit fees. In the Middle East and North African region context, Hassan and Naser (2013) found no significant relationship between profitability and audit fees in Emirates. Extensive studies have been done on the relationship between profitability and ETR, which have produced mixed results (Derashid \& Zhang, 2003; Hadjidema et al., 2016; Kim \& Im, 2017; Yinka \& Uchenna, 2018). This mixed result was obtained due to the other factors that worth to be examined. Thus, to have a deeper understanding of the relationship between profitability and aggressive tax planning, and the prominent role of NAS in ensuring the quality of tax planning strategy, this study incorporated NAS in the analysis. NAS in the previous study usually been used as an independent variable rather than moderating variable. Binding from the above discussion, this study hypothesizes that:

$\mathrm{H} 2$ : The relationship between profitability and aggressive tax planning is moderated by NAS fee.

\subsection{The Influence of NAS Fee on the Relationship Between Leverage and Aggressive Tax Planning}

Previous studies have found that companies that have higher debts are negatively associated with tax planning due to the interest deductibility. Prior studies have shown mixed results where a positive (Parisi, 2016; and Wahab et al., 2017), negative (Nomura, 2017; and Yinka and Uchenna, 2018) and insignificant (Vintilă, Gherghina, and Păunescu, 2018) relationship between leverage and ETR has been found in these studies. The positive result was also reported by Halperin and Lai (2015) in examining the relationship between leverage and audit fees (audit services and tax services). It has been indicated that companies with higher debt have paid higher audit fees due to the risk taken by the auditors in doing their job and also due to the greater risk of insolvency (Martinez, 2014). Besides, auditors who have provided NAS (tax services) have a positive relationship with leverage in private firms (Dobler, 2014). Nonetheless, no study has explored the moderating effect of NAS fee on the association between leverage and aggressive tax planning. Thus, this study investigates the moderating effect of NAS fee on the association between leverage and aggressive tax planning. This study, therefore, hypothesizes that:

H3: The relationship between leverage and aggressive tax planning is moderated by NAS fee

\subsection{The Influence of NAS Fee on the Relationship Between Capital Intensity and Aggressive Tax Planning}

Previous studies have extensively debated on the association between capital intensity and tax planning. Again mixed finding has been reported where Hadjidema et al. (2016) and Rashid, Noor, and Mastuki (2015) however found a negative relationship showing that higher capital intensity resulted in the lower ETR suggesting that company implement an aggressive tax planning. Delgado, Fernandez-Rodriguez, and Martinez-Arias (2014) and Vintilă et al. (2018) found a positive relationship between capital intensity and ETR. This usually against the industry practise where companies increase the ownership in capital asset to utilize the benefit of incentives. To dig more into the nature of the relationship between capital intensity and aggressive tax planning, we consider including NAS fee as it is related with the effort to have a better tax planning strategy by the companies. Since investment in plant, property and equipment (PPE) can reduce the company's tax payment, the payment for NAS fee is expected to influence this relationship. Thus, it is important to assess the moderating effect of NAS fee on the relationship between capital intensity and aggressive tax planning. Thus, this study hypothesizes that:

H4: The relationship between capital intensity and aggressive tax planning is moderated by NAS fee.

\subsection{The Influence of NAS Fee on the Relationship Between Inventory Intensity and Aggressive Tax Planning}

Inventory intensity is among the frequents variables used as determinants of aggressive tax planning strategy conducted by companies. High inventory is believed will yield to the high profit, but still, it will depend on how the management manages the inventory. Previous studies have found conflicting result in the relationship between inventory intensity and ETR. A negative association was reported suggesting that higher investment in inventory 
leads to a reduction in the tax payment (for example, Hadjidema et al., 2016; Savitri, 2017). On the other hand, some studies have found a positive result (for example Hsieh, 2012; Noor, Fadzilah, \& Mastuki, 2010; Vintilă et al., 2018) showing that company may pay the higher tax due to the turnover in inventory. To provide a new area of the discussion on the determinants of aggressive tax planning, this study continues the examination of the role of capital intensity on aggressive tax planning by introducing the moderating variable of NAS fee. NAS fee paid by companies is expected to influence the relationship between inventory intensity and aggressive tax planning. Thus, this study hypothesizes that:

H5: The relationship between inventory intensity and aggressive tax planning is moderated by NAS fee.

\subsection{The Influence of NAS Fee on the Relationship Between Financial Distress and Aggressive Tax Planning}

Despite the important role financial distress level in influencing companies' tax strategy, a limited number of studies are available to study such a relationship. Previous studies have found that a higher level of financial distress leads the companies to engage in aggressive tax planning (Cita \& Supadmi, 2019; Edwards, Schwab, \& Shevlin, 2016; Richardson, Taylor, \& Lanis, 2015; Sadjiarto et al., 2020) as they require high cash holding to continue operations. Since a higher level of financial distress reduces the amount of tax paid by the companies, the presence of NAS fee in such companies is expected to have a significant influence on the companies' aggressive tax planning activities. This is when companies are willing to pay more fees for planning purposes which may result to lower tax burden and increase their cash holding. Thus, this study hypothesizes that:

H6: The relationship between financial distress and aggressive tax planning is moderated by NAS fee.

\subsection{The Influence of NAS Fee on the Relationship Between Ethnicity and Aggressive Tax Planning}

Yatim, Kent, and Clarkson (2006) found that ethnicity has a negative relationship with audit fees. Studies which was conducted in Malaysia context found that Bumiputera-controlled firms pay lower audit fees compared to non-Bumiputera-controlled firms. However, the result of this study is inconsistent with the study by Johl, Subramaniam, and Mat Zain (2012) and Wahab, Zain, and Rahman (2015) where they found that Bumiputera-controlled firms pay a higher amount of audit fees for audit services. Wahab et al., (2017) also found that there is a negative relationship between ethnicity and aggressive tax planning for large companies, where Bumiputera-controlled firms are less aggressive in tax planning compared to the non-Bumiputera controlled firms. Considering the above results, integrating NAS in the analysis is important to look into the willingness of companies in investing money to seek professional opinion for aggressive tax planning strategies. Thus, this study hypothesizes that:

H7: The relationship between ethnicity and aggressive tax planning is moderated by NAS fee.

From the above discussion, it is worth to consider including NAS fee to get new insight into the discussion between size, profitability, leverage, capital intensity, inventory intensity, financial distress and ethnicity which commonly used variables in the aggressive tax planning determinants. The issue of NAS fee seems worth to be investigated due to the differences in terms of the variables used, changes in country' tax policy, culture and the other factors between each country and in the country itself. Therefore, this study is important to be conducted because it uses the current data, with the current tax policy, different characteristics of the sample used compared with the previous studies, and the new variables introduced that might influence the companies aggressive tax planning activities when the NAS fee is introduced. Furthermore, this study's result might give new avenue on aggressive tax planning topic, which focuses on the NAS fee in the taxation area.

\section{Research Design}

\subsection{Sample Selection and Data}

This study focuses on Malaysian companies listed on the ACE Market of Bursa Malaysia from 2014 to 2018 that were selected based on the criteria in Table 1. Companies listed on the ACE Market have been selected as a proxy for small and medium-sized companies. The data were collected from DataStream software and the downloaded annual reports. 
Table 1. Sample selection criteria

\begin{tabular}{ll}
\hline Criteria & No. of companies \\
\hline ACE market listed firms throughout the year & 119 \\
\hline Exclude: & 22 \\
\hline 1) Companies listed after 2014 & 2 \\
\hline 2) Finance/insurance/bank/trust companies & 19 \\
\hline 3) Companies with missing data & 55 \\
\hline 4) Loss-making companies a least in one of the years with negative profit & 21 x 5 years \\
\hline Final sample & 105 companies \\
\hline No of observations & \\
\hline
\end{tabular}

\subsection{Variable Specification and Measurement}

The dependent variable for this study is aggressive tax planning and being measured as differences between STR and ETR. The independent variables in this study are size, profitability, capital intensity, inventory intensity, leverage, financial distress, ethnicity. While the NAS fee is a moderating variable. All the independent variables and moderating variable are measured as indicated in Table 2.

Table 2. Variables measurement

\begin{tabular}{ll}
\hline Variables & Measurement \\
\hline Size (SIZE) & Log of total assets. \\
\hline Profitability (ROA) & Ratio of pre-tax income and total assets. \\
\hline Leverage (LEV) & Ratio of long term debt and shareholders' equity. \\
\hline Capital intensity (CAPINT) & Ratio of net property, plant and equipment and total assets. \\
\hline Inventory intensity (INVINT) & Ratio of total inventories and total assets. \\
\hline Financial distress (FD) & Athman Z-Score \\
\hline Ethnicity (ETHNICITY) & Percentage of Bumiputra directors on board \\
\hline Non-audit services fee (NASF) & Log of non-audit service fee \\
\hline
\end{tabular}

\subsection{Panel Regression Model}

This study conducted a regression analysis of balanced panel data based on the following equation:

$$
\begin{gathered}
\text { ATP }_{\text {it }}=\beta_{0}+\beta_{1} \text { SIZE }_{\text {it }}+\beta_{2} \text { ROA }_{\text {it }}+\beta_{3} \text { LEV }_{\text {it }}+\beta_{4} \text { CAPINT }_{\text {it }}++\beta_{5} \text { INVINT }_{\text {it }}+\beta_{6} \text { FD }_{\text {it }}+\beta_{7} \text { ETHNICITY }_{\text {it }}+\beta_{8} \text { NASF }_{\text {it }} \\
+\beta_{9} \text { SIZE }_{\text {it }} * \text { NASF }_{\text {it }}+\beta_{10} \text { ROA }_{\text {it }} * \text { NASF }_{\text {it }}+\beta_{11} \text { LEV }_{\text {it }} * \text { NASF }_{\text {it }}+\beta_{12} \text { CAPINT }_{\text {it }} * \text { NASF }_{\text {it }}+\beta_{13} \text { INVINT }_{\text {it }} * \text { NASF }_{\text {it }}+ \\
\beta_{14} \text { FD }_{\text {it }} * \text { NASF }_{\text {it }} \beta_{15} \text { ETHNICITY }^{*} \text { NASF }_{\text {it }}+\varepsilon_{\text {it }}
\end{gathered}
$$

Where,

ATP = Aggressive tax planning;

SIZE $=$ Size of the company;

ROA $=$ Return on assets;

LEV= Leverage of the company;

CAPINT = Capital intensity;

INVINT = Inventory intensity;

$\mathrm{FD}_{=}$Financial distress;

ETHNICITY $=$ Ethnicity of board of director; 
NASF=Non-audit services fee;

$\varepsilon=$ Error term;

$i t=$ Company $\mathrm{i}$ at time $\mathrm{t}$

\section{Empirical Result and Discussion}

The data for this study were analyzed using descriptive analysis and multiple regressions analysis. From the descriptive analysis, it is found that companies with NAS fee range from minimum of none to a maximum of 5.65 (result is not provided). This reveals that there are companies without NAS fee, and there are those with high NAS fee. According to Bursa Malaysia Listing Requirement, there is no minimum or maximum value for NAS fee. Thus, it confirms that companies are free to pay their auditors for services other than audit services but must disclose the amount of NAS fee in their annual report.

For the regressions analysis, several analyses have been made in panel data to choose the appropriate model. Firstly, the Breush-Pagan LM test was conducted to choose between Pooled OLS and the random-effects model. From the analysis, the P-value is 0.00 , which is less than 0.05 , thus rejecting the null hypothesis. Hence, the random-effects model is more appropriate. Secondly, to choose between the random-effects model and the fixed-effects model, the Hausman test was conducted. From this analysis, the P-value is 0.004 , which is less than 0.05 . Thus the fixed-effects model is more appropriate than the random-effects model. Due to heteroskedasticity and serial correlation problems, the robust estimators were run as advocated by Law (2014). The final result of hypotheses testing is shown in Table 3.

Table 3. Result of hypotheses testing

\begin{tabular}{lllll}
\hline Variables & Coef. & Std Err & t-value & $\mathbf{P}>(\mathbf{t})$ \\
\hline SIZE & -0.029 & 0.067 & -0.44 & 0.668 \\
\hline ROA & 0.935 & 0.369 & 2.54 & $0.020^{* *}$ \\
\hline LEV & -0.009 & 0.281 & -0.04 & 0.972 \\
\hline CAPINT & 0.087 & 0.092 & 0.94 & 0.358 \\
\hline INVENT & -0.264 & 0.296 & -0.89 & 0.383 \\
\hline FD & -0.113 & 0.047 & -2.38 & $0.027^{* *}$ \\
\hline ETHNICITY & 0.171 & 0.084 & 2.04 & $0.055^{* *}$ \\
\hline NASF & 0.000 & 0.006 & 0.02 & 0.983 \\
\hline SIZE*NASF & 0.095 & 0.033 & 2.84 & $0.010^{* * * *}$ \\
\hline ROA*NASF & 0.624 & 0.163 & 3.81 & $0.001^{* * *}$ \\
\hline LEV*NASF & -0.285 & 0.092 & -3.07 & $0.006^{* * *}$ \\
\hline CAPINT*NASF & 0.057 & 0.039 & 1.44 & 0.166 \\
\hline INVENT*NASF & 0.277 & 0.088 & 3.13 & $0.005^{* * *}$ \\
\hline FD*NASF & -0.661 & 0.015 & -4.17 & $0.000^{* * *}$ \\
\hline ETHNICITY*NASF & -0.090 & 0.033 & -2.66 & $0.015^{* * *}$ \\
\hline R-squared & 0.382 & & & \\
\hline N & 105 & & & \\
\hline
\end{tabular}

Notes:

1) $* * * * *$ and $*$ denote that the correlations are statistically significant at the $0.01,0.05$ and 0.10 , respectively.

2) The sample is panel data runs for 2014-2018 (strongly balanced) 


\subsection{Moderating Effect of NAS Fee on the Relationship Between Company Size and Aggressive Tax Planning (H1)}

As depicted in Table 3, the finding shows a positive and significant relationship (coefficient 0.095, t-value 2.84 and p-value 0.010). This indicates that one unit addition in the moderating variable (NASF) in company size leads to an increase by 0.095 of ATP at the $1 \%$ level. The result reveals that the presence of the NAS fee improves companies' tax planning due to auditors' role in giving effective consultation. The complex activities which need consultation and advice from auditors are one of the reasons why companies are willing to pay NAS fee. Therefore, the introduction of NAS fee as a moderating variable strengthens the relationship between company size and aggressive tax planning. Thus, $\mathrm{H} 1$ is accepted.

\subsection{Moderating Effect of NAS Fee on the Relationship Between Profitability and Aggressive Tax Planning (H2)}

The result in Table 3 shows a positive and significant relationship (coefficient 0.624, t-value 3.81 and p-value 0.001), which indicates that $\mathrm{H} 2$ is supported at the $\mathrm{p}<0.001$ level of significance. It shows that one unit addition in the moderating variable (NASF) in profitability leads to an increase of 0.624 in ATP at the $1 \%$ level. It could be stated that with the presence of NAS fee, companies engage more in tax planning activities when their profit is higher. Therefore, the introduction of NAS fee as a moderating variable strengthens the relationship between profitability and aggressive tax planning. Thus, $\mathrm{H} 2$ is accepted.

\subsection{Moderating Effect of NAS Fee on the Relationship Between Leverage and Aggressive Tax Planning (H3)}

As depicted in Table 3, the result shows a negative and significant relationship (coefficient -0.285 , t-value -3.07 and p-value 0.006), indicating that $\mathrm{H} 3$ is supported at the $\mathrm{p}<0.006$ level of significance. It shows that one unit addition in the moderating variable (NASF) in leverage leads to a decrease by 0.285 in ATP at the $1 \%$ level. Thus, there is a significantly negative moderation in the relationship between leverage and ATP for companies listed on the ACE market when the NAS fee is introduced. Therefore, $\mathrm{H} 3$ is accepted.

\subsection{Moderating Effect of NAS Fee on the Relationship Between Capital Intensity and Aggressive Tax Planning (H4)}

In Table 3, the results (coefficient 0.057, t-statistics 1.44 and p-value 0.166) reveals an insignificant and positive relationship (NASF*CAPINT) with ATP indicating that NAS fee does not moderate the relationship between CAPINT and ATP. Thus, H4 is rejected. One possible reason for the absence of support for the hypothesized relationship might due to low investment in PPE. Even, with the introduction of NAS fee, there is no significant relationship between capital intensity and aggressive tax planning for companies listed on the ACE market.

4.5 Moderating Effect of NAS Fee on the Relationship Between Inventory Intensity and Aggressive Tax Planning (H5)

The result of the regression analysis suggests that NAS fee moderates the relationship between INVENT and ATP. Thus, $\mathrm{H} 5$ is accepted. The result in Table 3 shows a positive and significant relationship (coefficient 0.2779 , $\mathrm{t}$-value 3.13 and p-value 0.005), which indicates that the hypothesis is supported at the $p<0.005$ level of significance. It shows that one unit addition in the moderating variable (NASF) in inventory intensity leads to an increase of 0.277 in ATP at the $1 \%$ level. It can be concluded that the presence of NAS fee improves companies' tax planning with the help of auditor giving effective consultation regarding inventory intensity. Therefore, the introduction of NAS fee as a moderating variable strengthens the relationship between inventory intensity and aggressive tax planning.

4.6 Moderating Effect of NAS Fee on the Relationship Between Financial Distress and Aggressive Tax Planning (H6)

Consistent with this hypothesis, the regression analysis result suggests that the NAS fee moderates the relationship between FD and ATP. Thus, H6 is accepted. The result in Table 3 shows the negative and significant relationship (coefficient -0.661 , t-value -4.17 and $\mathrm{p}$-value 0.000 ), which indicates that the hypothesis is supported at the $\mathrm{p}<0.001$ level of significance. It shows that one unit addition in the moderating variable (NASF) in FD leads to a decrease by 0.6614 in ATP at the $1 \%$ level. It can be concluded that the presence of NAS fee as a moderating variable strengthens the relationship between financial distress and aggressive tax planning.

\subsection{Moderating Effect of NAS Fee on the Relationship Between Ethnicity and Aggressive Tax Planning (H7)}

Very few studies have investigated the relationship between ethnicity and aggressive tax planning. However, with the various ethnic groups in Malaysia, this variable is considered as an important variable to be investigated. Table 3 reveals a significant and negative relationship (coefficient -0.090 , t-statistics -2.66 and p-value 0.015 ) which points out that NASF moderates the relationship between ETHNICITY and ATP; thus, H7 is accepted. The negative relationship shows that a board comprising Bumiputera directors is involved in less aggressive tax planning when companies hire NAS. Wahab et al. (2017) indicated that a Bumiputera board of directors is conservative in aggressive tax planning activities. This study finds that the interaction of NAS fee strengthens the relationship between ethnicity and aggressive tax planning. According to Minnick and Noga (2010), the board of directors plays 
an important role in companies. More importantly, companies which have diverse ethnicities are very strong in influencing ATP.

\section{Conclusion}

This study proposes NAS fee as a moderating variable in the relationship between the independent variables (size, profitability, leverage, capital intensity, inventory intensity, financial distress, ethnicity) and the dependent variable (aggressive tax planning). The use of NAS fee instead of a tax fee is due to the unavailability of the exact amount of tax fee data in the companies' annual reports. Due to that, this study uses NAS fee as a variable because the tax fee is also included in the NAS fee.

In this study, seven hypotheses were developed to investigate the effect of the moderating variable. The results show that NAS fee moderates all the relationship between company size, profitability, leverage, inventory intensity, financial distress and ethnicity with aggressive tax planning except for capital intensity. Thus, from the result, it can be concluded that the NAS fee plays an important role in influencing companies tax planning activities. Therefore, this study contributes to knowledge in the financial accounting and taxation research fields, particularly by providing empirical evidence from emerging markets on the introduction of NAS fee as a moderating variable in the studied relationships.

This study has limitations that need to be addressed. The sample comprises only listed companies on the ACE Market of Bursa Malaysia from 2014 to 2018. Further research might enlarge the sample size by performing a comparative study in different tax regimes or increase the time span of the study. Besides, the methodology used in this study can be used as a basis for studies on tax-related matters in other countries and regions that might produce different results due to the different settings to enrich the research on corporate tax planning behaviour.

\section{References}

Adhikari, A., Derashid, C., \& Zhang, H. (2006). Public policy, political connections, and effective tax rates: Longitudinal evidence from Malaysia. Journal of Accounting and Public Policy, 25(5), 574-595. https://doi.org/10.1016/j.jaccpubpol.2006.07.001

Baron, R. M., \& Kenny, D. A. (1986). The moderator-mediator variable distinction in social psychological research: conceptual, strategic, and statistical considerations. Journal of Personality and Social Psychology, 51(6), 1173-1182.

Bottaro, W., Castro, D. L., \& Peleias, I. R. (2015). Determinants of audit fees: a study in the companies listed. In 38th AnPAD Meeting (pp. 261-273). https://doi.org/10.1590/1808-057x201501560

Burggrael, S., Wtrin, C., \& Wei, F. (2017). Discovering the concealed benefits of auditor-provided tax services.

Choudhary, P., \& Koester, A. (2017). Auditor-provided tax services and income tax estimation error.

Chyz, J. A., Naiker, V., Gal-Or, R., \& Sharma, D. (2017). The influence of auditor provided tax planning and tax compliance services in the tax transparency era. In Tax-Symposium-2017 (pp. 1-54).

Cita, I. G. A., \& Supadmi, N. L. (2019). Pengaruh financial distress dan good corporate governance pada praktik tax avoidance. E-Journal Akauntansi, 29(3), 912-927. Retrieved from http://u.lipi.go.id/1352700000

Delgado, F. J., Fernandez-Rodriguez, E., \& Martinez-Arias, A. (2014). Effective tax rates in corporate taxation: A quantile regression for the EU. Engineering Economics, 25(5), 487-496. https://doi.org/10.5755/j01.ee.25.5.4531

Derashid, C., \& Zhang, H. (2003). Effective tax rates and the "industrial policy" hypothesis: Evidence from Malaysia. Journal of International Accounting, Auditing and Taxation, 12(1), 45-62. https://doi.org/10.1016/S1061-9518(03)00003-X

Dhamara, G. P., \& Violita, E. S. (2018). The influence of financial distress and independence of board of commissioners on tax aggressiveness. Advances in Economics, Business and Management Research, 55(Iac 2017), 81-86.

Dobler, M. (2014). Auditor-provided non-audit services in listed and private family firms. Managerial Auditing Journal. https://doi.org/10.1108/MAJ-07-2013-0908

Donohoe, M. P., \& Knechel, R. W. (2014). Does corporate tax aggressiveness influence audit pricing?. Contemporary Accounting Research, 31(1), 284-308. https://doi.org/10.1111/1911-3846.12027

Edwards, A., Schwab, C., \& Shevlin, T. (2016). Financial constraints and cash tax savings. Accounting Review, 91(3), 
859-881. https://doi.org/10.2308/accr-51282

Eskandar, H., \& Ebrahimi, P. (2020). Tax Avoidance and Institutional Ownership: Active vs Passive Ownership. International Journal of Finance and Managerial Accounting, 5(17), 95-106.

Firth, M. (1997, April). The Provision of Non-audit Services. Journal of Business Finance \& Accounting, 24, 511-525.

Ganesan, Y., Haron, H., Ismail, I., \& Pitchay, A. A. (2017). Do Small and Medium Practitioners' ( SMPs') Service Quality and Non-Audit Service Fees Paid Matters?. The Mediating Role of Satisfaction of Small Medium Enterprises ( SMEs ). Global Business and Management Research: An International Journal, 9(4), 391-409.

Hadjidema, S., Stamatopoulos, I., \& Eleftheriou, K. (2016). Explaining corporate effective tax rates before and during the financial crisis: evidence from Greece. Munich Personal RePEc Archive. Retrieved from https://mpra.ub.uni-muenchen.de/73787/

Halperin, R., \& Lai, K.-W. (2015). The relation between auditor-provided tax service fees and audit fees after the sarbanes-oxley act. Journal of Accounting, Auditing \& Finance, 30(3), 341-372. https://doi.org/10.1177/0148558X14560900

Haron, H., Ismail, I., Ganesan, Y., \& Hamzah, Z. (2016). Audit exemption for small and medium enterprise: perceptions of Malaysian auditors. Asian Academy of Management Journal, 21(2), 153-182. https://doi.org/10.21315/aamj2016.21.2.7

Hassan, Y. M., \& Naser, K. (2013). Determinants of audit fees: evidence from an emerging economy. International Business Research, 6(8), 13-25. https://doi.org/10.5539/ibr.v6n8p13

Higgins, D., Omer, T. C., \& Phillips, J. D. (2015). The influence of a firm's business strategy on its tax aggressiveness. Contemporary Accounting Research, 32(2), 674-702. https://doi.org/10.1111/1911-3846.12087

Hogan, B., \& Noga, T. (2015). Auditor-provided tax services and long-term tax avoidance. Review of Accounting and Finance, 14(3), 285-305. https://doi.org/http://dx.doi.org/10.1108/RAF-10-2013-0116

Hsieh, Y. (2012). New evidence on determinants of corporate effective tax rates. African Journal of Business Management, 6(3), 1177-1180. https://doi.org/10.5897/AJBM11.1522

Hussin, S. N. A., \& Noor, R. M. (2012). The dual role of auditor-provided tax services (ATS) in SMEs tax planning. In CHUSER 2012 - 2012 IEEE Colloquium on Humanities, Science and Engineering Research (pp. 351-356). https://doi.org/10.1109/CHUSER.2012.6504338

Januarti, I., \& Diponegoro, U. (2018). The effect of size, profitability, risk, complexity, and independent audit committee on audit fee. Jurnal Dinamika Akuntansi, 10(2), 136-145. https://doi.org/10.15294/jda.v10i2.16607

Johl, S., Subramaniam, N., \& Mat Zain, M. (2012). Audit Committee and CEO Ethnicity and Audit fees: Some Malaysian evidence. International Journal of Accounting, 47(3), 302-332. https://doi.org/10.1016/j.intacc.2012.07.002

Joshi, P. L., \& Al-bastaki, H. (2000). Determinants of Audit Fees: Evidence from the Companies Listed in Bahrain. International Journal of Auditing, 4, 129-138.

Kasim, F. M., \& Saad, N. (2019). Determinants of corporate tax avoidance strategies among multinational corporations in Malaysia. International Journal of Research in Business Studies and Management, 6(5), 1-6.

Kim, J. H., \& Im, C. C. (2017). The study on the effect and determinants of small-and medium-sized entities conducting tax avoidance. Journal of Applied Business Research, 33(2), 375-390.

Klassen, K. J., Lisowsky, P., \& Mescall, D. (2016). The role of auditors, Non-Auditors, and internal tax departments in corporate tax aggressiveness. In Accounting Review (Vol. 91, pp. 179-205). https://doi.org/10.2308/accr-51137

Laguir, I., Elbaz, J., \& Laguir, L. (2015). Empirical evidence on SMEs' tax management. Applied Economics Letters, 22(14), 1133-1137. https://doi.org/10.1080/13504851.2015.1008757

Law, S. H. (2018). Applied Panel Data Analysis: short panels. Universiti Putra Malaysia Press, Serdang, Selangor.

Martinez, A. L. (2014). Association between independent auditor fees and firm value: a study of brazilian public companies. Journal of Modern Accounting and Auditing, 10(4), 442-450.

Martinez, A. L. (2017). Tax aggressiveness: a literature survey. Journal of Education and Research in Accounting, 
11 (special edition), 104-121. https://doi.org/http://dx.doi.org/10.17524/repec.v11i0.1724

McGuire, S. T., Omer, T. C., \& Wang, D. (2012). Tax avoidance: Does tax-specific industry expertise make a difference?. Accounting Review, 87(3), 975-1003. https://doi.org/10.2308/accr-10215

Mgammal, M. H. (2015). The Effect of Tax Planning and Corporate Governance on Tax Disclosure in Malaysia. Universiti Utara Malaysia.

Minnick, K., \& Noga, T. (2010). Do corporate governance characteristics influence tax management?. Journal of Corporate Finance, 16(5), 703-718. https://doi.org/10.1016/j.jcorpfin.2010.08.005

Musah, A. (2017). Determinants of Audit fees in a Developing Economy: Evidence from Ghana. International Journal of Academic Research in Business and Social Sciences, 7(11), 716-730. https://doi.org/10.6007/IJARBSS/v7-i11/3510

Nomura, H. (2017, June). What Determines Japanese Corporate Effective Tax Rates?. Evidence from Firms Listed on the Tokyo Stock Exchange, 1-18. Retrieved from http://apeaweb.org/confer/seoul17/papers/Nomura_Hiroyasu.pdf

Noor, R. M., Fadzillah, N. S., \& Mastuki, N. (2010). Corporate Tax Planning: A Study On Corporate Effective Tax Rates of Malaysian Listed Companies. International Journal of Trade, Economics and Finance, 1(2), 189-193.

Noor, R. M., Mastuki, N., \& Bardai, B. (2008). Corporate effective tax rates: a study on malaysian public listed companies. Malaysian Accounting Review, 7(1), 1-20.

Oktaviyani, R., \& Munandar, A. (2017). Effect of solvency, sales growth, and institutional ownership on tax avoidance with profitability as moderating variables in indonesian property and real estate companies. Binus Business Review, 8(3), 183. https://doi.org/10.21512/bbr.v8i3.3622

Parisi, V. (2016). The determinants of Italy's corporate tax rates: an empirical investigation. Public and Municipal Finance, 5(4), 7-14. https://doi.org/10.21511/pmf.05(4).2016.01

Pham, N. K., Duong, H. N., Pham, T. Q., \& Ho, N. T. T. (2015). Audit firm size, audit fee, audit reputation and audit quality: the case of listed companies in vietnam. Asian Journal of Finance \& Accounting, 26(69), 261-273. https://doi.org/10.5296/ajfa.v9i1.10074

Pratama, A. (2017). Company Characteristics, Corporate Governance and Aggressive Tax Avoidance Practice: A Study of Indonesian Companies. Review of Integrative Business and Economics Research, 6(4), 70-81.

Rashid, N. N., Noor, R. M., \& Mastuki, N. A. (2015). Longitudinal Study of Corporate Tax Planning: Analysis on Companies' Tax Expense and Financial Ratios. Pertanika Journal of Social Sciences \& Humanities, 23(S), 109-120.

Richardson, G., Taylor, G., \& Lanis, R. (2015). The impact of financial distress on corporate tax avoidance spanning the global financial crisis: Evidence from Australia. Economic Modelling, 44, 44-53. https://doi.org/10.1016/j.econmod.2014.09.015

Rusmanto, T., \& Waworuntu, S. R. (2015). Factors Influencing Audit Fee in Indonesian Publicly Listed Companies Applying GCG. Procedia - Social and Behavioral Sciences, 172, 63-67. https://doi.org/10.1016/j.sbspro.2015.01.336

Sadjiarto, A., Hartanto, S., Natalia, \& Octaviana, S. (2020). Analysis of the effect of business strategy and financial distress on tax avoidance. Journal of Economics and Business, 3(1), 238-246. https://doi.org/10.31014/aior.1992.03.01.193

Salihu, I. A., Annuar, H. A., Normala, S., \& Obid, S. (2015). Foreign investors' interests and corporate tax avoidance: Evidence from an emerging economy. Journal of Contemporary Accounting \& Economics, 11(2), 138-147. https://doi.org/10.1016/j.jcae.2015.03.001

Santos, C., Cerqueira, A., \& Brandao, E. (2015, December). Audit Fees, Non-Audit Fees and Corporate Performance, 1-27.

Saremi, H., Mohammadi, S., \& Nezhad, B. M. (2016). Relationships between Effective Tax Rate and Audit Fees: Evidence from Tehran Stock Exchange. International Journal of Management and Humanities, 2(7), 120-127.

Savitri, E. (2017). Determinants of Effective Tax Rate of the Top 45 largest listed companies of Indonesia. International Journal of Management Excellence, 9(3), 1183-1188. 
Tee, E., Boadi, L. A., \& Opoku, R. T. (2016). The Effect of Tax Payment on the Performance of SMEs: The Case of Selected SMEs in Ga West Municipal Assembly. ResearchGate, 8(20), 119-125.

The Star. (2017, January 18). Tackling aggressive tax planning. The Star Online. Retrieved from https://www.thestar.com.my/opinion/columnists/the-star-says/2017/01/18/tackling-aggressive-tax-planning

Vintilă, G., Gherghina, Ş. C., \& Păunescu, R. A. (2018). Study of effective corporate tax rate and its influential factors: empirical evidence from emerging european markets. Emerging Markets Finance and Trade, 54(3), 571-590. https://doi.org/10.1080/1540496X.2017.1418317

Wahab, E. A. A., Ariff, A. M., Marzuki, M. M., \& Sanusi, Z. M. (2017). Political connections, corporate governance, and tax aggressiveness in Malaysia. Asian Review of Accounting, 25(3), 424-451. https://doi.org/10.1108/ARA-05-2016-0053

Wahab, E. A. A., Zain, M. M., \& Rahman, R. A. (2015). Political connections: a threat to auditor independence?. Journal of Accounting in Emerging Economies, 5(2), 222-246. https://doi.org/10.1108/JAEE-03-2012-0013

Yatim, P., Kent, P., \& Clarkson, P. (2006). Governance structures, ethnicity, and audit fees of Malaysian listed firms. Managerial Auditing Journal, 21(7), 757-782. https://doi.org/10.1108/02686900610680530

Yinka, M. S., \& Uchenna, C. E. (2018). Firm specific determinants of corporate effective tax rate of listed firms in Nigeria. Journal of Accounting and Taxation, 10(2), 19-28. https://doi.org/10.5897/JAT2017.0288

\section{Copyrights}

Copyright for this article is retained by the author(s), with first publication rights granted to the journal.

This is an open-access article distributed under the terms and conditions of the Creative Commons Attribution license (http://creativecommons.org/licenses/by/4.0/). 